\title{
The ICT basic skills: Contribution to student social media utilization activities
}

\author{
Supardi Supardi ${ }^{1}$, Juhji Juhji ${ }^{2}$, Intan Azkiyah ${ }^{3}$, Birru Muqdamien ${ }^{4}$, Aan Ansori ${ }^{5}$, Iwan Kurniawan ${ }^{6}$, \\ Ahmad Fitriadi Sari ${ }^{7}$ \\ 1,2,4,5 Universitas Islam Negeri Sultan Maulana Hasanuddin Banten, Indonesia \\ ${ }^{3}$ Universitas Islam Negeri Syarif Hidayatullah Jakarta, Indonesia \\ ${ }^{6}$ Kementerian Agama Kabupaten Tangerang, Indonesia \\ ${ }^{7}$ Sekolah Tinggi Pesantren Darunna'im, Indonesia
}

\begin{tabular}{|c|c|}
\hline Article Info & ABSTRACT \\
\hline Article history: & This study aimed to analyze the contribution of Information and \\
\hline Received Mar 21, 2020 & Communications Technology (ICT) basic skills to student social media \\
\hline Revised Dec 21, 2020 & regression analysis. A total of 144 students selected randomly participated in \\
\hline Accepted Jan 19, 2021 & $\begin{array}{l}\text { this research. The research instrument used a five-scale questionnaire, } \\
\text { consisting of } 32 \text { items of ICT skill instruments and } 20 \text { items for social media }\end{array}$ \\
\hline Keywords: & $\begin{array}{l}\text { utilization instruments. The results showed a high level of ICT students' basic } \\
\text { skills and social media use activities. There is a contribution of basic ICT }\end{array}$ \\
\hline $\begin{array}{l}\text { Education } \\
\text { ICT basic skills } \\
\text { Social media }\end{array}$ & $\begin{array}{l}\text { skills to student social media utilization activities. The higher of the basic } \\
\text { skill of ICT causes the higher the level of activity utilization of their social } \\
\text { media. Research recommendations suggest efforts to improve students' basic } \\
\text { ICT skills. }\end{array}$ \\
\hline
\end{tabular}

This is an open access article under the $\underline{C C B Y-S A}$ license.

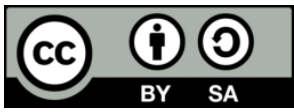

Corresponding Author:

Juhji Juhji

Faculty of Education and Teacher Training

Universtas Islam Negeri Sultan Maulana Hasanuddin Banten

Banten, Indonesia

E-mail: juhji@uinbanten.ac.id

\section{INTRODUCTION}

The Programme for International Student Assessment (PISA) study reported that 94 to 95 percent of students worldwide have a computer at home, while in Indonesia only $21 \%$ and students can access the internet at home is still below $10 \%$ [1]. Along with that, internet use in Indonesia has increased dramatically. It was shown by a large number of social media users. Social media is a computer feature that allows a person to share and exchange information [2]. The presence of social media causes people to be able to build global communication and socialize [3] through internet networks easily. Accordingly, humans can connect with each other through communication and social networking interactions to improve their well-being [4]. Previous studies have found social media benefits in education [5, 6] such as in lectures [7] and inter-college promotions.

Nowadays, in some regions of Indonesia, there are some problems related to the basic skills of ICT, such as the absence of electricity, hardware facilities, computer viruses [8], the high cost of procurement and use of ICT facilities [9]. According to Pelgrum and Law, in the success of ICT, there are serious obstacles such as the lack of multiple computers, the lack of educator skills, the difficulty of integrating ICT in the learning process, inadequate supervision, and inadequate training opportunities [10]. In addition to these problems, other issues are highlighted in the implementation of ICT in the world of education, such as the 
problem of lack of funds and human resources, the low culture of change in the adaptation of ICT development, and progress in education. In this case, regulations are required regarding the barriers found in ICT so that the basic integration of ICT in the learning process can be resolved.

Nowadays, mobile technology has gained increased focus among academics as a way to enable unlimited learning in space and time [11]. To support this, ICT basic skills are needed in education, although the process is slow and complex [12]. The use of ICT and the increasing reliance of today's society on information and knowledge have resulted in new challenges for educational institutions [13, 14]. Several studies have looked at how ICT can be utilized in the teaching and education process $[11,15,16]$. The success of the use of ICT in education depends on the attitude and acceptance of teachers towards the development of technology [17].

According to Ismail's report [18] cited by Papadakis [17], stated that the success or failure of the implementation of mobile technology learning depends on the Teacher factor. Teachers are believed to have played an important role in the process of changing the adoption of mobile technology [19, 20]. The utilization of social media in learning through mobile technology is allegedly influenced by basic ICT skills such as Computer Operations, Software Applications, Internet Skills, and World Wide Web Skills.

The growth of mobile devices and smartphones facilitates unlimited information, has brought about changes in human thinking in every lifeline, including in higher education in the 21 st century. Higher education students use various social media tools in various activities [3]. They use Whatsapp Group and Facebook Group to communicate and share information related to learning tasks provided by lecturers. These two social media tools are their most commonly used.

Social media is one of the most widely used communication tools by a wide audience, especially young people [21]; as an interactive online communication channel. Murray [22] stated that social media provides an opportunity for people to reflect themselves, to form societies, to create an environment of cooperation and sharing. In addition, according to Piskorski [23] social media is used to communicate with external parties in various platforms such as Facebook, WhatsApp, Twitter, Google Classroom, Youtube, Skype, Imo, Instagram, Blogs, and other social media.

As ICT evolves, the use of social media from day to day has increased dramatically and become part of the daily life of mankind. Anisa's [24] research found the influence of social media on students' learning outcomes. Goes along with it, Manumpil [25] also reported a relationship between the use of gadgets and the level of achievement of students at State High School 9 Manado, Indonesia. The findings of this study suggest the influence of ICT basic skills on the utilization of social media. Based on these problems, this study aims to analyze the contribution of ICT basic skills to student social media utilization activities.

\section{RESEARCH METHOD}

The research method starts with the theoretical framework used in the research. Figure 1 shows the conceptual framework for analyzing the contribution of ICT basic skills to student social media utilization activities.

\begin{tabular}{|c|c|}
\hline Basic Skills of ICT \\
Computer Operational \\
Application Software \\
Internet Skills \\
World Wide Web Skills
\end{tabular}$\rightarrow \begin{gathered}\text { Utilization of Social Media } \\
\text { Information } \\
\text { Entertainment } \\
\text { Friendship networking } \\
\text { Education }\end{gathered}$

Figure 1. Conceptual framework of ICT basic skills toward social media utilization activities

\subsection{Research approach}

This research uses quantitative research. According to Schumacher and McMillan [26], quantitative research is a form of research that examines objects, symptoms, events, or data that can be measured numerically (scale, index, formula, and so on) and analysis using statistics.

\subsection{Population and sample}

The population in this study was 233 students. The sample size was 144 students; they were selected referring to the Sample Table from Ahmad and Halim [27]. The population comes from semester 1, 3, 5, and seven students at the Islamic Religious College of Banten State, Indonesia. Because the populations are different then sampling is done proportionally stratified random sampling. This refers to the opinion of Sugiyono [28]. 


\subsection{Research instruments}

Research instrument is questionnaire with five scales. Instruments of ICT's basic skills refer to Herman [29] and Priatna [30]. ICT skill instruments include dimensions: 1) Computer operation, consisting of eight instrument items; 2) Application, consisting of eight instrument items; 3) Internet skills, consisting of eight instruments, and 4) World Web Skill, consisting of eight instruments. The instrument of social media use refers to Nurdin [31] which includes dimensions: 1) Information requirements, consisting of four items; 2) Entertainment needs, consisting of four items; 3) Friendship network, consisting of six items; and 4) Education, consisting of six items.

\subsection{Validity and reliability}

The instrument validity test is conducted through the Pearson Correlation test and an instrument reliability test is conducted through Cronbach's Alpha Test. Both are done with SPSS Version 16.0. The validity and reliability test results can be found in Table 1.

Table 1. Test results of research instruments on ICT basic skills and social media utilizing activities

\begin{tabular}{ccccc}
\hline Dimensions & Instruments & Pearson correlation & Cronbach's alpha & Description \\
\hline Computer operation & $\mathrm{CO}_{1}-\mathrm{CO}_{8}$ & $0.322-0.846$ & 0.791 & Valid \& Reliable \\
Application & $\mathrm{A}_{1}-\mathrm{A}_{8}$ & $0.653-0.898$ & 0.913 & Valid \& Reliable \\
Internet skills & $\mathrm{IS}_{1}-\mathrm{IS}_{8}$ & $0.931-0.959$ & 0.984 & Valid \& Reliable \\
World web skill & $\mathrm{WWS}_{1}-\mathrm{WWS}_{8}$ & $0.562-0.855$ & 0.863 & Valid \& Reliable \\
Information requirements & $\mathrm{IR}_{1}-\mathrm{IR}_{4}$ & $0.377-0.937$ & 0.808 & Valid \& Reliable \\
Entertainment needs & $\mathrm{EN}_{1}-\mathrm{EN}_{4}$ & $0.627-0.905$ & 0.808 & Valid \& Reliable \\
Friendship network & $\mathrm{FN}_{1}-\mathrm{FN}_{6}$ & $0.613-0.749$ & 0.729 & Valid \& Reliable \\
Education & $\mathrm{E}_{1}-\mathrm{E}_{6}$ & $0.352-0.831$ & 0.719 & Valid \& Reliable \\
Adj. R Square $=0.657$ & & & \\
\hline
\end{tabular}

\subsection{Research data analysis}

Inference regression analysis is selected to analyze the data of the results of the study. The regression analysis is used for forecasting purposes, where there are dependent variables and independent variables. Descriptive analysis is used to describe what happens to selected samples [32] as suggested by Brey [33] that descriptive analysis tries to understand the results by analyzing the meaning of concepts built into research models. While the average analysis refers to Jamil [34], it provides low, medium, and high criteria on average.

\section{RESULTS}

The results of ICT basic skill descriptive statistical analysis and student social media utilization activities can be seen in Table 2. Table 2 illustrates the average ICT Basis Skills is higher than the average social media utilization activity $(4.10>3.90)$ and inversely proportional to the standard deviation $(0.90<1.03)$. The average computer operational dimensions on ICT Basic Skills variables are smaller than the dimensions of software applications, internet skills, and World Wide Web skills.

The analysis of the contribution of ICT's basic skills to student social media utilization activities is based on the regression analysis in Table 3. Table 3 shows the regression test results with test F. The calculation results show that the value of $\mathrm{F}$ is 64.97 while the value of the $\mathrm{F}$ table is at 0.01 and 3.91. These results suggest that the $\mathrm{F}$ count is greater than the $\mathrm{F}$ table, so it can be stated that the regression of the direction of the $\mathrm{Y}$ coefficient over $\mathrm{X} 1, \mathrm{X} 2, \mathrm{X} 3$, and $\mathrm{X} 4$ is very significant. So, the regression equation $=$ $-27.67+0.339 \mathrm{X} 1+0.232 \mathrm{X} 2+0.901 \mathrm{X} 3+1.705 \mathrm{X} 4$ can be used to describe the relationship between basic ICT skills including: computer operations, software applications, internet skills and web skills with social media utilization activities. 
Table 2. ICT basic skills descriptive statistics and social media utilizing activities

\begin{tabular}{cccc}
\hline Variables and dimensions & Mean & Standard deviation & Criteria \\
\hline ICT basic skills & 4.10 & 0.90 & High \\
Computer operational & 3.88 & 1.04 & Medium \\
Software application & 4.20 & 0.86 & High \\
Internet skills & 4.03 & 0.94 & High \\
World wide web skills & 4.27 & 0.78 & High \\
Social media utilizing activities & 3.90 & 1.03 & High \\
Information & 3.98 & 1.04 & High \\
Entertainment & 3.80 & 1.08 & Medium \\
Friendship networking & 3.92 & 0.99 & High \\
Education & 3.88 & 1.04 & Medium \\
\hline
\end{tabular}

Table 3. Analysis of ICT basic skills regression with social media utilization activities

\begin{tabular}{|c|c|c|c|c|c|c|c|}
\hline & \multirow[b]{2}{*}{ Model } & \multicolumn{2}{|c|}{$\begin{array}{l}\text { Unstandardized } \\
\text { coefficients }\end{array}$} & \multirow{2}{*}{ Sign } & \multirow{2}{*}{$\mathrm{F}$} & \multirow[t]{2}{*}{$\mathrm{R}$} & \multirow{2}{*}{$\mathrm{R}^{2}$} \\
\hline & & B & Std. Error & & & & \\
\hline \multirow[t]{5}{*}{1} & (Constant) & -27.672 & 7.049 & .000 & 64.97 & .807 & .657 \\
\hline & Computer operational & .339 & .135 & .013 & & & \\
\hline & Software application & .232 & .240 & .335 & & & \\
\hline & Internet skills & .901 & 146 & .000 & & & \\
\hline & WWW skills & 1.705 & .255 & .000 & & & \\
\hline
\end{tabular}

The strength of the relationship between ICT basic skill variables includes computer operations, software applications, internet skills, and web skills with student social media utilization activities indicated by a correlation coefficient of 0.807 so that the coefficient of the determination relationship between ICT basic skills and student social media utilization activity is equal to 0.657 . This means that $65.7 \%$ of the variations that occur in social media utilization activities by students can be influenced by the basic skills of ICT. Thus, it can be concluded that the basic skills of ICT include: computer operations, software applications, internet skills, and World Wide Web skills together contributing $65.7 \%$ to increasing student social media utilization activities.

\section{DISCUSSION}

The results of this study show that the basic skills of ICT students are high. The basic abilities of high ICT were also found in the Priatna study [30] which showed that the lecturer's ICT utilization skill level was $74.08 \%$, computer operations, computer software applications, internet skills, and website skills. While Kristyaningrum's research [35] found students' ICT skills varied: $22 \%$ low, $20 \%$ medium, $48 \%$ high, and $20 \%$ very high. Pavlik and Dennis [36] in their research explained that education by utilizing ICT is more effective and profitable than the use of conventional instruction technology, in terms of $30 \%$ more timesaving and 40\% more improving student achievement. The results of the study are in line with the research conclusions of ICT's contribution to academic settings and identify the current needs and challenges faced by students when interacting with ICT [37]. ICT skills are quite high according to this study, in contrast to the results of Woreta's research, et al. [38], finding that students from Gondar University School of Medicine and Health Sciences have insufficient knowledge in ICT and the ability to use ICT is very low. So Woreta, et al. [38], defines needs, computer laboratories, incorporates information-based disciplines and strengthens health informatics training to equip students in the use of ICT.

ICT skills possessed by students should be observed at a high stage. This is in line with the Ministry of Information and Communication of the Ministry of National Education of the Republic of Indonesia which has formulated seven strategic roles by utilizing ICT, namely: 1) As a science warehouse; 2) Learning aids; 3) Educational facilities; 4) Supporting education administration; 5) Management aids; and 6) Educational infrastructure [39]. Perbawaningsih [40] states that to be able to organize ICT-based learning and provide basic ICT skills, it is necessary: 1) ICT devices, both hardware, software and data software with certain operational capability standards [41]; 2) Human Resources that have a positive attitude towards technology and high ICT Literacy; 3) A conducive institutional and institutional climate.

The results of this study show that the activity of social media utilization by students is high. The results of this study support the results of Ghifari, et al. [42] which found that the use of social media by the public for social functions is the majority choice, followed by information functions and commercial functions. The results of Rianingtias, Sobri, and Nurabadi [43] showed: 1) The level of social media use in the learning of students of the Faculty of Education of Malang State University is in the intermediate category; 2) The level of learning achievement of students of the Faculty of Education of Malang State 
University is in the intermediate category; 3) The use of social media for the achievement of student learning faculty of education, Malang State University is effective.

The contribution of ICT skills to social media use activities is in line with BrckaLorenz's, et al. [44], of the increasing use of technology in some aspects of student life, as well as the interaction of teaching and learning in higher education. Unlike Alkan and Meinck's research [45], it shows that there is not much influence on the use of ICT for social communication. Previous studies have suggested that social media that can be accessed over the Internet is a source of information $[32,33]$. The results of this study prove that social media users over the internet can indeed be the most important and useful source of information for anyone as stated by Smith [46]. Nurdin's research [31] shows that 98 percent of students admit to using the internet to search for information related to photos and website links. Social media became one of the alternative options for discussing group work and communicating among the academic community [47, 48]. Social media is also used as a medium to search for and exchange information relevant to academic tasks [49]. The originality of ideas emerging from the digital generation is sometimes a tipping point of access to information exchange. Social media can also be used as a means of entertainment especially to meet the needs of individuals who feel the silence [50]. Nurdin's research [31] found 83 respondents claimed to use the Internet as a means of entertainment, but the entertainment in question was less related to downloading songs and watching movies online. Nisiforou and Laghos [51] stated that the use of social media for entertainment needs is a variant of the social media benefits of the most chosen students.

The results of research on the use of social media by students in this study are in line with the results of research that shows Indonesia always ranks in the top 10 users of the top four social media platforms in the world, which is the highest-ranking as Facebook users, ranked tenth in the world in YouTube users, the first rank of Twitter and G+ users [52]. This is in line with Loras [53] who made conclusions like Indonesian society with social media. These results can be supported by the fact that the Internet can be one way to build a wider network of friends as previously learned. For example, Ellison, Steinfield, and Lampe [54] found that students who built a network of friends on the Internet had more friends than students who did not use them. Nurdin's [31] research found $94 \%$ of students admitted to using the internet to access various social media sites that support friendships online.

Social media is also an important part of education. For example, to search for various scientific literature relating to the various subjects required [55]. Even the results of previous research show that $78 \%$ of American students use the Internet for the benefit of their school work. Students also use the Internet to connect with their teachers and also download various teaching materials [56]. Nurdin's research [31] found that $99 \%$ students use the internet to search for their course materials. The use of social media in student activities was also demonstrated by the results of Al-Rahmi and Zeki's research [57]. They say that social media is widely used by students to study the Qur'an and Hadith. They also assert that the platform provides comfort for students to exchange and share information with fellow students. Ólafsson, Livingstone, and Haddon's [58] research show that the most common online activities of children aged 9-16 in Europe are: using the internet for school work (85\%), playing games $(83 \%)$, watching video clips $(76 \%)$ and instant messaging (62\%). The results of this study are in line with the views of Treadaway and Smit [59] which state about the benefits of social media, namely: 1) The need to share information; 2) Proximity to residence; 3 ) Everyone is a source of information. It is also in line with the views of Delerue [60] and He [61] the pillars of social media are communication, collaboration, education, and entertainment.

The results showed that there were a contribution and relationship of basic ICT skills with social media utilization activities by students. Basic ICT contributions to social media use activities for educational activities are expressed by Poore [62] and Kist [63] about the advantages of social media, namely: 1) Preparing materials for class, can teach students how to use the internet and how to manage privacy; 2) Used to update the information provided to students, on changes in assignments and value-added; 3) Can be a means of communication with each other outside of school; 4) Can be used to view news reports to improve curriculum and knowledge; 5) Can connect students with other classes anywhere to learn different cultures.

Baird [64] and Friesen [65] said that ICT's basic skills of using NING (social networking media widely used in education) were good enough to facilitate project groups. In line with that Klopfer, et al. [66] state that social networking technology can be used to communicate assignments, class discussions, and materials that can support homework support. With regard to the use of basic ICT skills, Kurniali [67] concluded internet skills are an effective knowledge management infrastructure. ICT-based social use skills can also be used as a tool to collaborate with all parties associated with the organization, not just internally, as in traditional knowledge management concepts. Social media invites anyone interested to participate by contributing open feedback, commenting, and sharing information in a fast and unlimited time [68]. Sujoko's trial results [69] using ICT (computer, LCD projector, e-mail, and WEB) for learning media in SMP 1 Geger Madiun stated that the use of ICT as a learning medium certainly requires basic ICT skills, both teachers and 
educators. Kristyaningrum's results [35] also show that there is a positive and significant relationship between ICT skill levels and students' perceptions of E-learning use.

\section{CONCLUSION}

This study concluded that there is a contribution to the basic skills of ICT for students' social media utilization activities. Basic ICT skills such as computer operations, software applications, internet skills, and WWW Skills have influenced students' social media utilization activities such as information needs, entertainment needs, friendship networks, and education. Thus, it is recommended for educators to improve their students' basic ICT skills because the basic abilities of ICT have manifestly influenced the social media utilization of students. For future research, it is expected to develop learning software applications for students.

\section{REFERENCES}

[1] A. Schleicher, K. Zimmer, J. Evans, and N. Clements, PISA 2009 Assessment Framework: Key Competencies in Reading, Mathematics and Science. OECD Publishing (NJ1), 2009.

[2] S. Siddiqui and T. Singh, "Social media its impact with positive and negative aspects," International Journal of Computer Applications Technology and Research, vol. 5, no. 2, pp. 71-75, 2016.

[3] M. Norhailawati, et al., "The Power of Social Networking Sites: Student Involvement toward Education," International Journal of Evaluation and Research in Education IJERE, vol. 8, no. 3, pp. 549-556, 2019.

[4] R. Kraut, S. Kiesler, B. Boneva, J. Cummings, V. Helgeson, and A. Crawford, "Internet paradox revisited," Journal of Social Issues, vol. 58, no. 1, pp. 49-74, 2002.

[5] M. Moran, J. Seaman, and H. Tinti-Kane, Teaching, Learning, and Sharing: How Today's Higher Education Faculty Use Social Media. Babson Survey Research Group, 2011.

[6] J. Juhji and P. Nuangchalerm, "Interaction between Scientific Attitudes and Science Process Skills toward Technological Pedagogical Content Knowledge," Journal for the Education of Gifted Young Scientists, vol. 8, no. 1 , pp. $1-16,2020$.

[7] M. D. Roblyer, M. McDaniel, M. Webb, J. Herman, and J. V. Witty, "Findings on Facebook in higher education: A comparison of college faculty and student uses and perceptions of social networking sites," The Internet and higher education, vol. 13, no. 3, pp. 134-140, 2010.

[8] B. Sumintono, S. A. Wibowo, N. Mislan, and D. H. Tiawa, "Use of information and communication technology in teaching: Survey on Junior Science Teachers in Indonesia,” Jurnal Pengajaran MIPA, vol. 17, no. 1, pp. 122-131, 2012.

[9] A. Akbar and N. Noviani, "Challenges and solutions in the development of educational technology in Indonesia," in Proceedings of National Seminar of Postgraduate Program Universitas PGRI Palembang, 2019.

[10] W. J. Pelgrum and N. W. Y. Law, ICT in education around the world: Trends, problems and prospects. UNESCO: International Institute for Educational Planning, 2003.

[11] K. Mac Callum and L. Jeffrey, "The influence of students' ICT skills and their adoption of mobile learning," Australasian Journal of Educational Technology, vol. 29, no. 3, 2013.

[12] F. A. Inan and D. L. Lowther, "Factors affecting technology integration in K-12 classrooms: A path model," Educational Technology Research and Development, vol. 58, no. 2, pp. 137-154, 2010.

[13] S. Papadakis, "Creativity and innovation in European education. Ten years eTwinning. Past, present and the future," International Journal of Technology Enhanced Learning, vol. 8, no. 3-4, pp. 279-296, 2016.

[14] K. Drossel, B. Eickelmann, and J. Gerick, "Predictors of teachers' use of ICT in school-the relevance of school characteristics, teachers' attitudes and teacher collaboration," Education and Information Technologies, vol. 22, no. 2, pp. 551-573, 2017.

[15] G.-J. Hwang and P.-H. Wu, "Applications, impacts and trends of mobile technology-enhanced learning: a review of 2008-2012 publications in selected SSCI journals," International Journal of Mobile Learning and Organisation, vol. 8, no. 2, pp. 83-95, 2014.

[16] M. Kalogiannakis and S. Papadakis, "An evaluation of Greek educational Android apps for preschoolers," in 12th Conference of the European Science Education Research Association (ESERA), Dublin City University and the University of Limerick, Dublin, Ireland, 2017, pp. 21-25.

[17] S. Papadakis, "Evaluating pre-service teachers' acceptance of mobile devices with regards to their age and gender: a case study in Greece," International Journal of Mobile Learning and Organisation, vol. 12, no. 4, pp. 336-352, 2018.

[18] I. Ismail, S. N. Azizan, and T. Gunasegaran, "Mobile learning in malaysian universities: are students ready?" International Journal of Interactive Mobile Technologies (iJIM), vol. 10, no. 3, pp. 17-23, 2016.

[19] B. W. O'Bannon and K. M. Thomas, "Mobile phones in the classroom: Preservice teachers answer the call," Computers \& Education, vol. 85, pp. 110-122, 2015.

[20] T. Wang, "Overcoming Teachers' Concerns-Where Are We in the Harnessing of Mobile Technology in K-12 Classrooms in Hong Kong?" in Churchill D., Lu J., Chiu T., Fox B. (eds). Mobile Learning Design. Springer, Singapore, 2016, pp. 239-248. 
[21] E. P. Yildiz, M. Çengel, and A. Alkan, "Social Media Attitudes among Vocational School Students," International Journal of Evaluation and Research in Education (IJERE), vol. 8, no. 3, pp. 384-391, 2019.

[22] C. Murray, "Schools and social networking: Fear or education," Synergy Perspectives: Local, vol. 6, no. 1, pp. 8-12, 2008.

[23] M. J. Piskorski, "Social strategies that work," Harvard Business Review, vol. 89, no. 11, pp. 116-22, 166, 2011.

[24] A. Anisa and E. Ernawati, "The influence of social media on the biology of public high school students in Makassar city," Binomial, vol. 3, no. 1, pp. 39-48, 2020.

[25] B. Manumpil, A. Y. Ismanto, and F. Onibala, "The relationship between the use of gadgets and the level of achievement of students in public high school 9 Manado" Jurnal Keperawatan, vol. 3, no. 2, 2015.

[26] J. Schumacher and J. H. McMillan, Research in education: A conceptual introduction, 5th Ed. New York, Longman, 2001.

[27] H. Ahmad and H. Halim, "Determining Sample Size for Research Activities," Selangor Business Review, vol. 2, no. 1, pp. 20-34, 2017.

[28] S. Sugiyono, Educational research methods: Quantitative, qualitative, and R\&D approaches. Bandung: Alfabeta, 2013.

[29] H. D. Surjono, "The role information and communications technology (ICT) in enhancing the innovative learning process (in Bahasa)," Seminar Nasional Pendidikan \& Saintec, 2013, vol. 18.

[30] S. Priatna, "ICT usage skills, CTL learning strategies and achievement-motivation of students in the Department of Islamic Religious Education Faculty of Tarbiyah and Teacher of the State Islamic Institute Sultan Maulana Hasanuddin Banten," Tanzhim, vol. 1, no. 01, pp. 65-78, 2017.

[31] N. Nurdin, "Analysis of internet adoption and utilization among college students in Palu city," Jurnal Elektronik Sistem Informasi dan Komputer, vol. 1, no. 1, pp. 49-52, 2015.

[32] K. V. Deore, "The educational advantages of using internet," International Educational E-Journal, vol. 1, no. 2, pp. 111-112, 2012.

[33] P. Brey, "Evaluating the social and cultural implications of the internet," ACM SIGCAS Computers and Society, vol. 36, no. 3, pp. 41-48, 2006

[34] A. Jamil, "Fertilization of culture of investigation among school teachers: an assessment," Thesis, Universitas Kebangsaan Malaysia, Malaysia, 2002.

[35] N. P. Kristyaningrum, "ICT skill level relationship with student perception of e-learning use," Thesis, Department of Informatics Engineering, Faculty of Engineering Universitas Negeri Yogyakarta, Jogjakarta, 2011.

[36] J. V. Pavlik and E. E. Dennis, New Media Technology: Cultural and Commercial Perspectives, 2nd ed. Boston: Allyn and Bacon, 1998.

[37] A. Joshi, J. Meza, S. Costa, D. M. P. Perin, K. Trout, and A. Rayamajih, "The role of information and communication technology in community outreach, academic and research collaboration, and education and support services (IT-CARES)," Perspectives in health information management, vol. 10, Fall, pp. 1-15, 2013.

[38] S. A. Woreta, Y. Kebede, and D. T. Zegeye, "Knowledge and utilization of information communication technology (ICT) among health science students at the University of Gondar, North Western Ethiopia," BMC Medical Informatics and Decision Making, vol. 13, no. 1, p. 31, 2013.

[39] P. Indrajit, Managemen Pendidikan Tinggi Modern. Yogyakarta: Andi Offset, 2006.

[40] Y. Perbawaningsih, "Plus minus of ICT usage in higher education students," Procedia-Social and Behavioral Sciences, 2013, vol. 103, no. 26, pp. 717-724.

[41] C. E. Watson, M. Johanson, M. Loder, and J. Dankiw, "Effects of high-stakes testing on third through fifth grade students: Student voices and concerns for educational leaders," Journal of Organizational Learning and Leadership, vol. 12, no. 1, pp. 1-11, 2014.

[42] M. Ghifari, V. E. Mustika, H. K. Rosidah, and A. Kirana, "Social media utilization by student," in Proceedings of the National Seminar on Strengthening Individuals in the Era of the Information Revolution, Surakarta, 2010.

[43] H. Rianingtias, A. Y. Sobri, and A. Nurabadi, "Effectiveness of social media use towards student learning achievement of faculty of education, Malang State University," Thesis, Department of Education Administration faculty of education, Malang State University, 2017.

[44] A. BrckaLorenz, H. Haeger, J. Nailos, and K. Rabourn, "Student perspectives on the importance and use of technology in learning," Indiana University: Association for Institutional Research Annual Forum, 2013.

[45] M. Alkan and S. Meinck, "The relationship between students' use of ICT for social communication and their computer and information literacy," Large-scale Assessments in Education, vol. 4, no. 1, p. 15, 2016.

[46] A. G. Smith, "Testing the surf: criteria for evaluating Internet information resources," Public-Access Computer Systems Review, vol. 8, no. 3, pp. 1-14, 1997.

[47] I. Hussain, "A study to evaluate the social media trends among university students," Procedia-Social and Behavioral Sciences, 2012, vol. 64, pp. 639-645.

[48] J. Rowe, "Student use of social media: when should the university intervene?" Journal of Higher Education Policy and Management, vol. 36, no. 3, pp. 241-256, 2014

[49] M. Owusu-Acheaw and A. G. Larson, "Use of social media and its impact on academic performance of tertiary institution students: a study of students of Koforidua Polytechnic, Ghana," Journal of Education and Practice, vol. 6, no. 6, pp. 94-101, 2015.

[50] M. T. Whitty and D. McLaughlin, "Online recreation: The relationship between loneliness, internet self-efficacy and the use of the Internet for entertainment purposes," Computers in Human Behavior, vol. 23, no. 3, pp. 1435-1446, 2007.

Int J Eval \& Res Educ, Vol. 10, No. 1, March 2021: 222 - 229 
[51] E. Nisiforou and A. Laghos, "Examining the effect of gender identity on the use of social media technology: A higher education approach," Journal of Arts and Humanities, vol. 4, no. 4, pp. 16-32, 2015.

[52] D. Chaffey, "Global social media research summary 2016," Smart Insights: Social Media Marketing, 2016.

[53] S. Loras, "Social media in Indonesia: big numbers with plenty of room to grow," ClickZ, 2016. [Online]. Available: https://www.clickz.com/social-media-in-indonesia-big-numbers-with-plenty-of-room-to-grow/94062/

[54] N. B. Ellison, C. Steinfield, and C. Lampe, "The benefits of Facebook "friends:" Social capital and college students' use of online social network sites," Journal of Computer-Mediated Communication, vol. 12, no. 4, pp. 1143-1168, 2007.

[55] M.-J. Tsai and C.-C. Tsai, "Information searching strategies in web-based science learning: The role of Internet self-efficacy," Innovations in Education and Teaching International, vol. 40, no. 1, pp. 43-50, 2003.

[56] A. Lenhart, M. Simon, and M. Graziano, "The Internet and Education: Findings of the Pew Internet \& American Life Project," Pew Internet and American Life Project, Washington, 2001.

[57] W. M. Al-Rahmi and A. M. Zeki, "A model of using social media for collaborative learning to enhance learners' performance on learning," Journal of King Saud University-Computer and Information Sciences, vol. 29, no. 4, pp. 526-535, 2017.

[58] K. Ólafsson, S. Livingstone, and L. Haddon, Children's use of online technologies in Europe: a review of the European evidence base (revised edition). EU Kids Online, London, UK, 2014.

[59] C. Treadaway and M. Smith, Facebook marketing: An hour a day. John Wiley \& Sons, 2012.

[60] H. Delerue and W. He, "A review of social media security risks and mitigation techniques," Journal of Systems and Information Technology, vol. 14, no. 2, pp. 171-180, 2012.

[61] W. He, "A survey of security risks of mobile social media through blog mining and an extensive literature search," Information Management \& Computer Security, vol. 21, no. 5, 381-400, 2013.

[62] M. Poore, Using social media in the classroom: A best practice guide. SAGE Publications Ltd, 2015.

[63] W. Kist, "Class, get ready to tweet: Social media in the classroom," Our Children: The National PTA Magazine, vol. 38, no. 3, pp. 10-11, 2013.

[64] D. Baird, "The promise of social networks," Tech \& Learning, 2005.

[65] N. Friesen and S. Lowe, "The questionable promise of social media for education: Connective learning and the commercial imperative," Journal of Computer Assisted Learning, vol. 28, no. 3, pp. 183-194, 2012.

[66] E. Klopfer, S. Osterweil, J. Groff, and J. Haas, "The instructional power of digital games, social networking, simulations, and how teachers can leverage them," Boston: The Education Arcade, vol. 1, pp. 20, 2009.

[67] S. Kurniali, "The role of social media on the internet in the implementation of knowledge management process," ComTech: Computer, Mathematics and Engineering Applications, vol. 2, no. 1, pp. 167-174, 2011.

[68] A. M. Kaplan and M. Haenlein, "Users of the world, unite! The challenges and opportunities of Social Media," Business Horizons, vol. 53, no. 1, pp. 59-68, 2010.

[69] S. Sujoko, "Utilization of information and communication technology as a learning medium in SMP Negeri 1 Geger Madiun,” Jurnal Kebijakan dan Pengembangan Pendidikan, vol. 1, no. 1, pp. 71-77, 2013. 